Journal of Computer Networks, Architecture and
High Performance Computing

Volume 3, Number 1, January 2021

https://doi.org/10.47709/cnahpc.v3i1.939
Submitted : 26 February 2021

Accepted : 10 March 2021

Published : 14 March 2021

\title{
Implementation of HSV- based Thresholding Method for Iris Detection
}

\author{
Fajrul Islami \\ Universitas Putra Indonesia YPTK Padang \\ fajrul_islami@upiyptk.ac.id
}

\begin{abstract}
Image thresholding is one of the most frequently used methods in image processing to perform digital image processing. Image thresholding has a technique that can separate the image object from its background. This is a technique that is quite good and effective for segmenting love. In this study, the threshold method used will be combined with the HSV mode for color detection. The threshold method will separate the object and the image background, while HSV will help improve the segmentation results based on the Hue, Saturation, Value values to be able to detect objects more accurately. Segmentation is carried out using the original input image without preprocessing or direct segmentation. As we know that in digital image processing, there are steps that are usually done to get a good input image, namely pre-processing. In this pre-processing stage, processes such as image conversion and image intensity changes are carried out so that the input image is better. Therefore, even though the input image is used without going through the pre-processing stage, the object can be segmented properly based on the color type of the object. The results of this segmentation can later be used for recognition and identification of image objects. The results of the test method for object segmentation achieved a color similarity level of $25 \%$, with an accuracy rate of $75 \%$ in detecting uniform color objects. So that this method can be one of the most effective methods in segmenting image objects without pre-processing or direct thresholding.
\end{abstract}

Keywords: Threshold, HSV, Image, Iris, Direct Threshold

\section{INTRODUCTION}

Object segmentation is an important step in the detection of an object in a digital image. By performing the segmentation stage, image components can be separated into several color parts (Mardiah, 2020). And also the most optimal algorithm in determining the object area (Sun \& Wei, 2020). The methods used for the image segmentation stage are very diverse and give different results on their detection results. One of the methods used in image segmentation is the threshold method. It is very efficient to use for digital image processing (Mousavirad \& Ebrahimpour-Komleh, 2020). Image thresholding is one of the most frequently used methods in image processing to perform digital image processing. Image thresholding has a technique that can separate the image object from its background. Thresholding is one of the important processes in digital image processing (Heryanto et al., 2020). This is a fairly good technique for segmenting love. In this study, the threshold method used will be combined with the HSV mode for color detection. HSV is a responsive and representative image processing method (Aqthobilrobbany et al., 2020). Digital images can be classified by the segmentation method based on the components used as the reference for object separation. Where segmentation is a supporter in increasing accuracy in texture extraction (Premana et al., 2020). The reference that is often used for digital image segmentation is the color of the object. Color is very influential on object detection (Sitohang \& Sindar, 2020). Color models that are often used in digital image segmentation are RGB and HSV. The basic color in RGB is a color that is used as a benchmark whose color will appear universally whose color can be changed into codes (Sari, 2020). HSV, which stands for Hue (H), Saturation (S), and Value (V), separates luminance or image intensity from chrominance or color information (Liu et al., 2012). Human color perception is based on a combination of three primary colors, namely Red (R), Green (G) and Blue (B). The application of various linear or nonlinear transformations to the RGB representation leads to the formation of different color models (Mandal \& Chaudhuri, 2020). The three components have their respective intensity ranges and are the primary color components. HSV is a digital image color model which consists of three elements, namely Hue, Saturation, and Value (Sinaga \& Marpaung, 2020).

* Corresponding author

This is an Creative Commons License This work is licensed under a Creative

Commons Attribution-NoDerivatives 4.0 International License. 


\section{Journal of Computer Networks, Architecture and High Performance Computing}

Volume 3, Number 1, January 2021

https://doi.org/10.47709/cnahpc.v3i1.939
Submitted : 26 February 2021

Accepted : 10 March 2021

Published : 14 March 2021

Therefore in this study the theme of Image Segmentation Using the HSV-Based Threshold Method, where in this study the data that became the test image was an original image, so that object segmentation could be detected even though it had a different color intensity.

\section{LITERATURE REVIEW}

Segmentation is a technique that refers to the process of dividing a digital image into several segments. The use of image segmentation is usually to find objects and backgrounds of an image. Image segmentation is the process of labeling each pixel in an image so that pixels with the same label share certain visual characteristics. The result of image segmentation is a set of segments that collectively covers the entire image, or a set of contours extracted from the image. HSV modeling is a model that is more general than RGB modeling. This HSV model is more often used in computer visual applications. This HSV model, is a model that comes from the RGB color model, therefore to get the HSV color model you must first convert the color from RGB to become the HSV color model. HSV is a method for describing colors based on a mixture of color circles. Hue measures the angle of red at 0 degrees, green at 120 degrees, and blue at 240 degrees, Saturation shows the radius of the color level between dark (center) and white (outside). Meanwhile, Value regulates the brightness value that ranges from 0 to 100\% (Agaputra et al., 2013). The application of the image segmentation method has been widely used in research in detecting digital image objects. In previous research, the segmentation method used an optimization algorithm based on learning and training (TLBO) to find a suitable method for detecting the edge of a noisy digital image by eliminating the noise effect. By determining the frequency of the highest brightness intensity and not the average brightness (Hajipour \& Mehrdad, 2020). In another study using the Black Widow Optimization (BWO) method, this method is used to design the edge detection method of digital noise images. In this study, it is concluded that the determination of the threshold plays a significant role in the extraction of the image edges and the average brightness intensity of each area in the image and the mean of the data clustering process is not representative for the determination (Houssein et al., 2021). In other previous studies, image segmentation used the k-means method to improve image segmentation results (Sipkens \& Rogak, 2021). In another study using the linear histogram fuzzy entropy thresholding method to select the optimal threshold for color image segmentation (Kang et al., 2020).

\section{METHOD}

To assist in that preparation of the study is more clearly its phases. Keep in the framework of work to see the rare steps are carried out in complete problem. The framework of research that is used as follows:

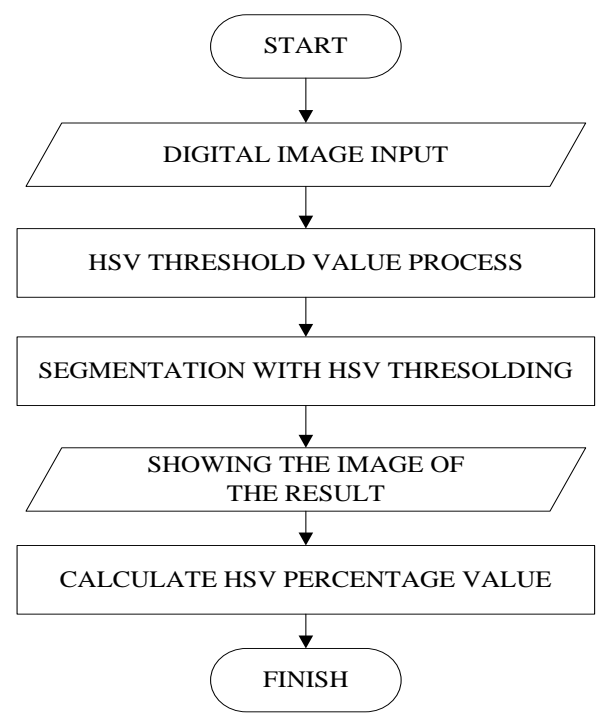

Figure 1. Framework Employment Research 


\section{Journal of Computer Networks, Architecture and High Performance Computing}

Volume 3, Number 1, January 2021

https://doi.org/10.47709/cnahpc.v3i1.939
Submitted : 26 February 2021

Accepted : 10 March 2021

Published : 14 March 2021

Based on the research framework, it can be explained as follows:

1. Digital Image Input

Reading the input image that has been provided, where the input image used is a color image.

2. HSV Threshold Value Process

Determine the threshold value used to display the HSV segmentation result image. One of the program commands to display the results of the HSV segmentation image:

Journal Program

for $i=1: m$

$$
\begin{aligned}
& \text { for } j=1: n \\
& d R=(\operatorname{abs}(\operatorname{Im}(i, j, 1)-R))^{\wedge} 2 \text {; } \\
& d G=(a b s(\operatorname{Im}(i, j, 2)-G))^{\wedge} 2 \text {; } \\
& d B=(a b s(\operatorname{Im}(i, j, 3)-B))^{\wedge} 2 \text {; } \\
& \text { check }=\text { sqrt (double }(d R+d G+d B)) \text {; } \\
& \text { if (check }<=T h \_R G B \text { ) } \\
& \text { cit_hasilRGB(i,j,: })=\operatorname{Im}(i, j,:) \text {; } \\
& \text { end } \\
& d H=c i t r a \_h s v(i, j, 1)-H 1 \text {; } \\
& S 2=\text { citra_hsv }(i, j, 2) \text {; } \\
& d V=\left(c i t r a \_h s v(i, j, 3)-V 1\right)^{\wedge} 2 \text {; } \\
& \text { Dcyl }=\operatorname{sqrt}\left(\text { double } \left(\left(d V+\left(S 1^{\wedge} 2\right)+\left(S 2^{\wedge} 2\right)\right)-\right.\right. \\
& (2 * S 1 * S 2 * \cos (d H)))) \text {; } \\
& \text { if }\left(D c y l<=T h \_H S V\right) \\
& \text { cit_hasilHSV(i,j,: })=\operatorname{Im}(i, j,:) \text {; } \\
& \text { end }
\end{aligned}
$$

end;

3. Segmentation with Threshold HSV

Doing Rail image input into the image space color HSV, based on the value of the threshold that has been determined.

4. Displaying the Result Imag

The image of the results of the segmentation will be displayed to within a figure, so that the acquired image of the results of the segmentation of HSV.

5. Conducting pehitungan Value Percentage of HSV

The image of the results of segmentation HSV are obtained will be calculated level of percentage of the value of the color on the hue, saturation, and value.

\section{RESULTS}

On stage this we will do testing of the data to get the results of the segmentation of the object. Here, using 5 pieces of image input iris eye native who has not done the stages of pre-processing. Testing program menggunakam software Matlab2018a that can be used for processing the image ditigal. The input image directly invoked through the program, then the program will be in the set point part of the object which is where will we get the segmentation of the object .. The object image will be segmented by colors that correspond to the area of the point of the object that we specify. This is where the method of the threshold and Model HSV will mendetksi parts of which alone that has a color that is in accordance with the local point of the object that we select. Point objects that will be in segmentation is area of a circle in the iris eye, by reason that the object image of the test that digunaka is the image of the iris eyes. The image of the iris eyes are used as follows :
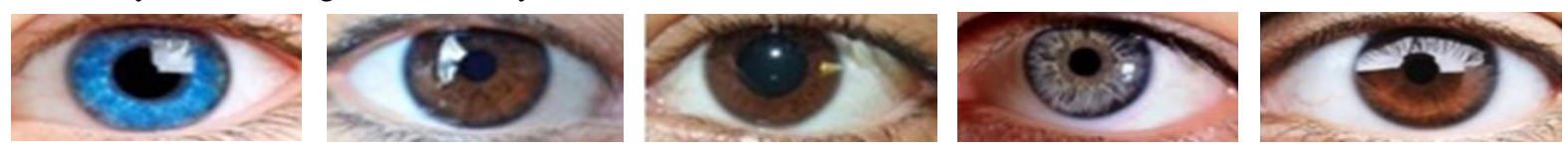
Journal of Computer Networks, Architecture and High Performance Computing

Volume 3, Number 1, January 2021

https://doi.org/10.47709/cnahpc.v3i1.939

Submitted : 26 February 2021

Accepted : 10 March 2021

Published : 14 March 2021

Figure 2. Iris 1

3.1 Testing Iris Image 1

Figure 3. Iris 2

Figure 4. Iris 3

Figure 5. Iris 4

Figure 6. Iris 5

Table 1. Iris Image Test Data

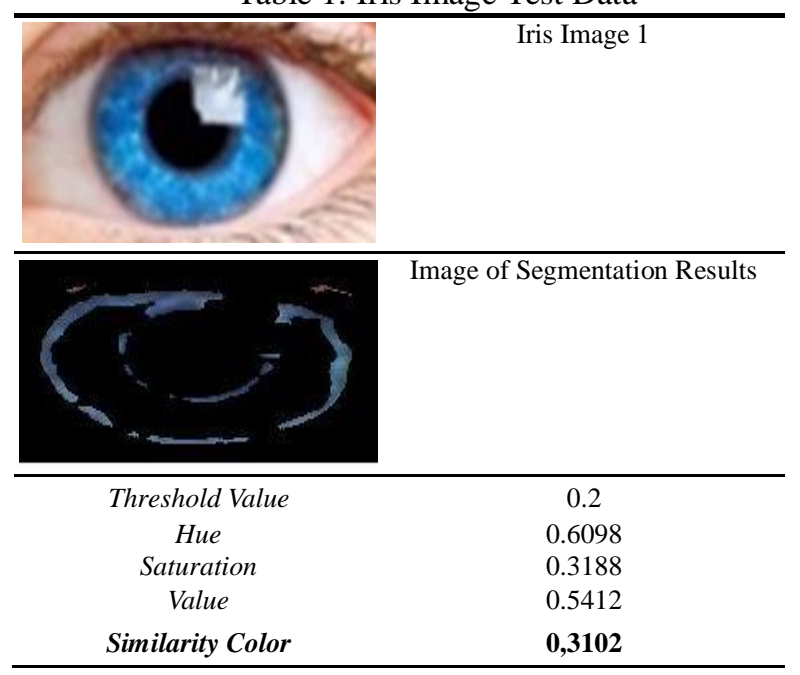

In Table 3.1 shows the data segmentation on the image of the original iris eye 1 with the similarity of colors 0.3102 , Hue 0.6098, Saturation 0.3188, Value 0.5412.

3.2 Testing Iris Image 2

Table 2. Iris Image Test Data

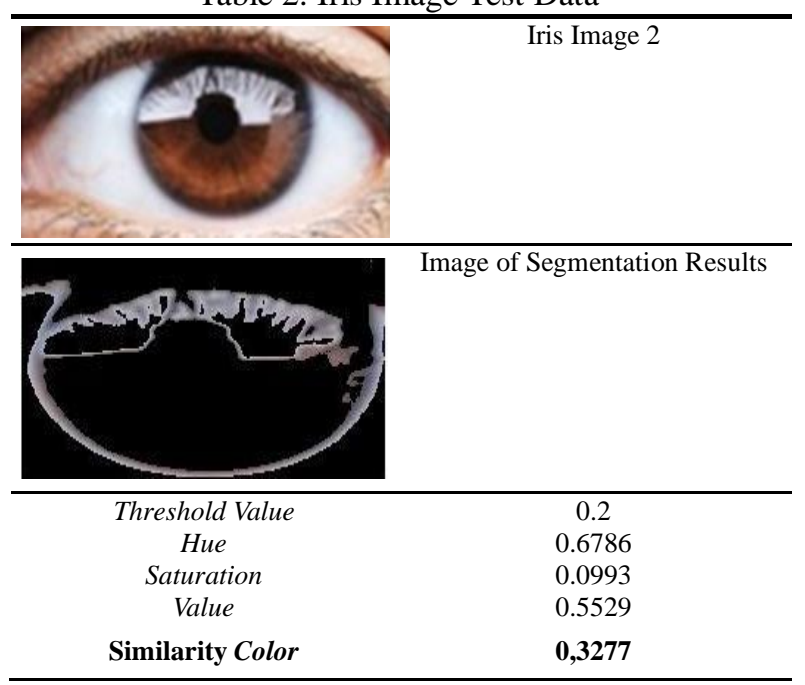

In Table 3.2 shows the data segmentation on the image of the original iris eye 1 with the similarity of colors 0.3277 , Hue 0.6786, Saturation 0.0993, Value 0.5529. 
3.3 Testing Iris Image 3

Table 3. Iris Image Test Data

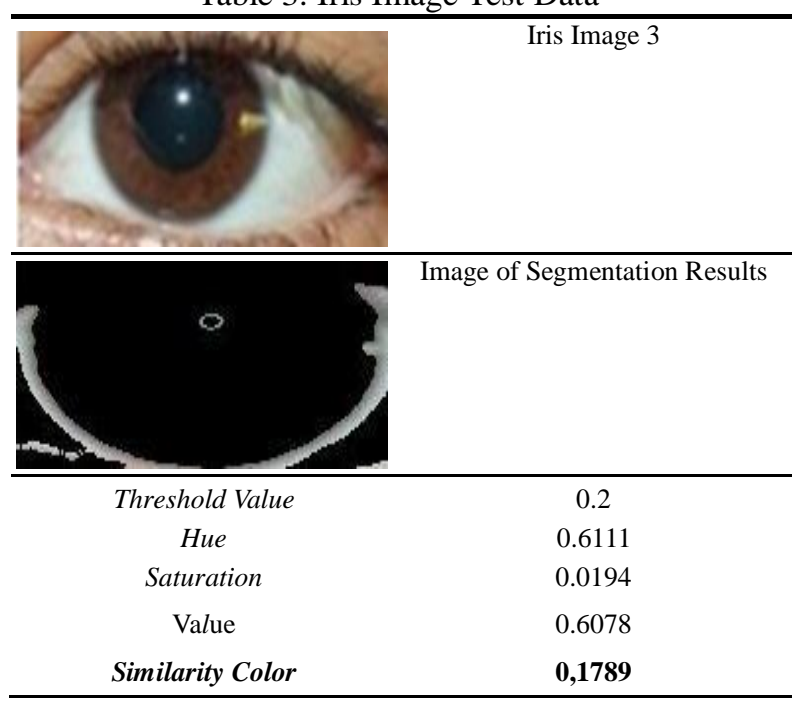

In table 3.3 shows the data segmentation on the image of the original iris eye 1 with the similarity of colors 0.1789 , Hue 0.6111, Saturation 0.0194, Value 0.6078.

3.4 Testing Iris Image 4

Table 4. of Iris Image Test Data 4

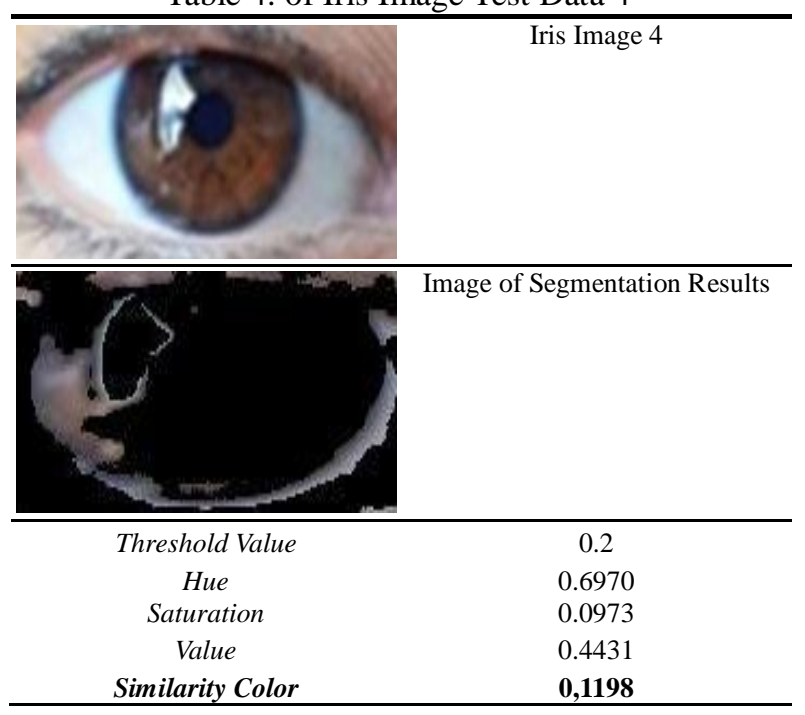

In table 3.4 shows the data segmentation on the image of the original iris eye 1 with the similarity of colors 0.1198 , Hue 0.6970, Saturation 0.0973, Value 0.4431. 


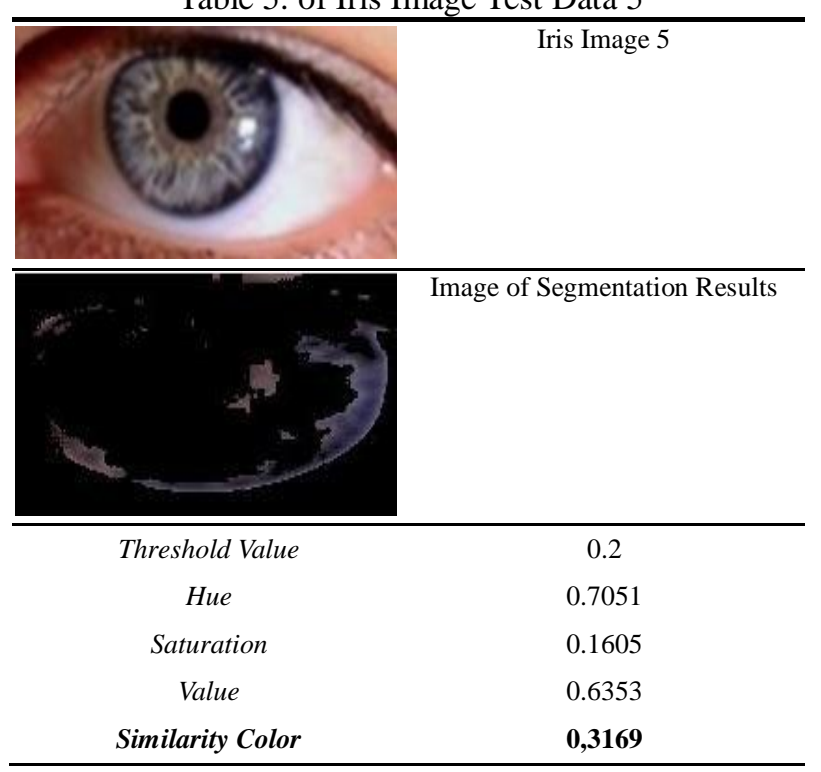

In table 3.5 shows the data segmentation on the image of the original iris eye 1 with the similarity of colors 0.3169 , Hue 0.7051, Saturation 0.1605, Value 0.6353.

Based on the data from the test to the image of the iris mata1, iris eye 2, iris eye 3 , iris eye 4 , and iris eyes 5 . Obtained results of segmentation by similarity of color with a value of $0.3102,0.3277,0.1789,0.1198,0.3169$. With the level of similarity lowest with a value of 0.1198 and the level of similarity largest by value of 0.3169 . For the data more details can be seen in Table 3.6.

Table 6. Value of Hue, Saturation, Value, and Color Similarity

\begin{tabular}{lllll}
\hline Input Image & Hue & Saturation & Value & $\begin{array}{c}\text { Similarity } \\
\text { Colors }\end{array}$ \\
\hline $\begin{array}{l}\text { Image } \\
\text { Iris 1 }\end{array}$ & 0.6098 & 0.3188 & 0.5412 & 0.3102 \\
$\begin{array}{l}\text { Image } \\
\text { Iris 2 }\end{array}$ & 0.6786 & 0.0993 & 0.5529 & 0.3277 \\
$\begin{array}{l}\text { Image } \\
\text { Iris 3 }\end{array}$ & 0.6111 & 0.0194 & 0.6078 & 0.1789 \\
$\begin{array}{l}\text { Image } \\
\text { Iris 4 }\end{array}$ & 0.6970 & 0.0973 & 0.4431 & 0.1198 \\
$\begin{array}{l}\text { Image } \\
\text { Iris 5 }\end{array}$ & 0.7051 & 0.1605 & 0.6353 & 0.3169 \\
\hline $\begin{array}{l}\text { Maximum } \\
\text { Value }\end{array}$ & & & & 0.1198 \\
\hline $\begin{array}{l}\text { Minimum } \\
\text { Value }\end{array}$ & & & & 0.3277 \\
\hline \begin{tabular}{l} 
Average \\
\hline
\end{tabular} & & & $\mathbf{0 . 2 5 0 7}$ \\
\hline
\end{tabular}




\section{Journal of Computer Networks, Architecture and High Performance Computing}

Volume 3, Number 1, January 2021

https://doi.org/10.47709/cnahpc.v3i1.939
Submitted : 26 February 2021

Accepted : 10 March 2021

Published : 14 March 2021

\section{DISCUSSION}

Based on research conducted, the object segmentation uses the HSV-based Threshold method to detect the iris. In segmenting the iris object image, it is not preceded by the pre-processing stage, where the segmentation is carried out directly based on the HSV value in the specified image area. The object will be segmented based on the value of Hue, Saturation, Value, and from the HSV value, the color similarity value will be obtained. The color similarity value obtained for the iris image, namely iris $1=0.3102$, iris $2=0.3277$, iris $3=0.1789$, iris $4=0.1198$, iris $5=$ 0.3169 .

\section{CONCLUSION}

Mechanical direct segmentation by methods threshold-based HSV in general capable of detecting objects based on similarity of colors that exist. Here the method that is used is able to detect the passage of colors that are in the area of the circle iris eye. With the average degree of similarity of color $25 \%$, It 's signifies that although the image data input is not done pre-processing, method of threshold -based HSV is the segmentation is able to detect the color of the uniform with the color point of an object with a level of accuracy reached $75 \%$. If segmentation that generated quite well on the object image of the medical that has the combination of colors which is quite complex , the result of segmentation will be good again if tested using the object image with a color that is more common. By reason that, the method it can be used as the method that is most effective for segmenting the object image.

\section{REFERENCES}

Agaputra, M. D., Wardani, K. R., \& Siswanto, E. (2013). Pencarian Citra Digital Berbasiskan Konten dengan Ekstraksi Fitur HSV, ACD, dan GLCM. Jurnal Telematika, 8 (2), 8-13.

Aqthobilrobbany, A., Handayani, A. N., Lestari, D., Muladi, Asmara, R. A., \& Fukuda, O. (2020). HSV Based Robot Boat Navigation System. 2020 International Conference on Computer Engineering, Network, and Intelligent Multimedia (CENIM). doi:10.1109/cenim51130.2020.9297915.

Hajipour, K., \& Mehrdad, V. (2020). Edge Detection Of Noisy Digital Image Using Optimization Of Threshold And Self Organized Map Neural Network. Multimedia Tools and Applications, 80(4), 5067-5086. doi:10.1007/s11042-020-09942-y.

Heryanto, I. W. A., Artama, M., Segara, M. W., \& Gunadi, I. G. A. (2020). Segmentasi Warna dengan Metode Thresholding. Wahana Matematika dan Sains: Jurnal Matematika, Sains, dan Pembelajarannya, 14(1), 5464.

Houssein, E. H., Helmy, B. E., Oliva, D., Elngar, A. A., \& Shaban, H. (2021). A novel Black Widow Optimization algorithm for multilevel thresholding image segmentation. Expert Systems with Applications, 167, 114159. doi:10.1016/j.eswa.2020.114159.

Kang, C., Wu, C., \& Fan, J. (2020). Entropy-Based Circular Histogram Thresholding For Color Image Segmentation. Signal, Image and Video Processing, 15(1), 129-138. doi:10.1007/s11760-020-01723-2.

Mandal, S., \& Chaudhuri, S. S. (2020). Polyps Segmentation using Fuzzy Thresholding in HSV Color Space. 2020 IEEE-HYDCON. doi:10.1109/hydcon48903.2020.9242852.

Mardiah, H. S. (2020). Segmentasi Citra Untuk Pencarian Kode Warna Cat Menggunakan Metode Thershold HSV. Bulletin of Information Technology (BIT), 1(3), 134-143.

Mousavirad, S. J., \& Ebrahimpour-Komleh, H. (2020). Human Mental Search-Based Multilevel Thresholding For Image Segmentation. Applied Soft Computing, 97, 105427. doi:10.1016/j.asoc.2019.04.002.

Premana, A., Bhakti, R. M. H., \& Prayogi, D. (2020). Segmentasi K-Means Clustering Pada Citra Menggunakan Ekstrasi Fitur Warna dan Tekstur. Jurnal Ilmiah Intech: Information Technology Journal of UMUS, 2(01), 8997.

Sari, B. M. (2020). Identifikasi Tingkat Kematangan Buah Strawberry Berdasarkan Warna RGB dengan Menggunakan Metode Regionprops. TIN: Terapan Informatika Nusantara, 1(5), 225-230.

Sinaga, A. S., \& Marpaung, E. (2020). Segmentasi Warna HSV Telapak Tangan Untuk Deteksi Bakteri Pada Pendemi Covid 19. Fountain of Informatics Journal, 5(3), 1-5. 
Journal of Computer Networks, Architecture and

High Performance Computing

Submitted : 26 February 2021

Volume 3, Number 1, January 2021

https://doi.org/10.47709/cnahpc.v3i1.939

Accepted : 10 March 2021

Published : 14 March 2021

Sipkens, T. A., \& Rogak, S. N. (2021). Technical Note: Using K-Means To Identify Soot Aggregates In Transmission Electron Microscopy Images. Journal of Aerosol Science, 152, 105699. doi:10.1016/j.jaerosci.2020.105699.

Sitohang, B., \& Sindar, A. (2020). Analisis Dan Perbandingan Metode Sobel Edge Detection Dan Prewit Pada Deteksi Tepi Citra Daun Srilangka. Jurnal Nasional Komputasi dan Teknologi Informasi, 3(3).

Sun, M., \& Wei, H. (2020). An improved cuckoo search algorithm for multi-level gray-scale image thresholding. Multimedia Tools and Applications, 79(47-48), 34993-35016. doi:10.1007/s11042-020-08931-5.

Z. Liu, W. Chen, Y. Zou, and C. Hu. (2012). Regions of interest extractionbased on HSV color space. IEEE International Conference on IndustrialInformatics (INDIN), 481-485. 